\title{
XXX. On the diffusion of liquids
}

\section{Thomas Graham F.R.S. F.C.S.}

To cite this article: Thomas Graham F.R.S. F.C.S. (1850) XXX. On the diffusion of liquids, Philosophical Magazine Series 3, 37:250, 254-281, DOI: 10.1080/14786445008646597

To link to this article: http://dx.doi.org/10.1080/14786445008646597

$$
\text { 册 Published online: } 30 \text { Apr } 2009 .
$$

Submit your article to this journal

LII Article views: 4

Q View related articles $\sqsubset$ 


\section{[ 254 ] \\ XXX. On the Diffusion of Liquids. By Thomas Graham, F.R.S., F.C.S.}

[Continued from p. 198.]

\section{Separation of Salts of different Bases by Diffusion.}

$\mathbf{I}^{\mathrm{T}}$ $T$ was now evident that inequality of diffusion supplies a method for the separation, to a certain extent, of some salts from each other, analogous in principle to the separation of unequally volatile substances by the process of distillation. The potash salts appearing to be always more diffusive than the corresponding soda saits, it follows, that if a mixed solution of two such salts be placed in the solution phial, the potash salt should escape into the water atmosphere in largest proportion, and the soda salt be relatively concentrated in the phial. This anticipation was fully verified.

(1.) A solution was prepared of equal parts of the anhydrous carbonates of potash and soda in 5 times the weight of the mixture of water. Diffused from a small thousand-grain phial of $1 \cdot 1$ inch aperture, into 6 ounces of water, for nineteen days, at a temperature above $60^{\circ}$, it gave a liquid of density $1 \cdot 0350$, containing a considerable quantity of the salts. Of these mixed salts, converted intu chlorides by the addition of hydrochloric acid, 9.39 grs., being treated with bichloride of platinum in the usual manner, gave 19.39 grs. of the double chloride of platinum and potassium, equivalent to $6.91 \mathrm{grs}$. of chloride of potassium; and left in solution 3.44 grs. of chloride of sodium : loss $0.04 \mathrm{gr}$. These chlorides represent 5.46 grs. of carbonate of potash and $3.12 \mathrm{grs}$. of carbonate of soda. The salts actually diffused out were therefore in the proportion of-

$$
\begin{aligned}
& \text { Carbonate of soda . . . . . } 36.37 \\
& \text { Carbonate of potash . . . . } \frac{63.63}{100 \cdot 00}
\end{aligned}
$$

(2.) In another similar experiment from a six-ounce phial into $8 \frac{1}{2}$ ounces of water, the liquid of the water-jar, after twentyfive days' diffusion, contained the two carbonates in nearly the same proportions as before, namely -

$$
\begin{aligned}
& \text { Carbonate of soda . . . . . . } 35 \cdot 2 \\
& \text { Carbonate of potash . . . . . . } 64.8 \\
& \overline{100 \cdot 0}
\end{aligned}
$$

(3.) A partial separation of the salts of sea-water was effected in a similar manner.

'The sea-water (from Brighton) was of density 1.0265. One 
thousand grs. of the liquid yielded 35.50 grs. of dry salts, of which $2 \cdot 165$ grs. were magnesia. The dry salts contain therefore $6 \cdot 10$ per cent. of that earth.

Six thousand-grain phials, of $1 \cdot 1$ inch aperture, were properly filled with the sea-water and placed in six tumblers, each of the last containing 6 ounces of water. Temperature about $50^{\circ}$. The diffusion was interrupted after eight days. The salts of the sea-water were now found to be divided as follows:Diffused into the tumblers $\quad . \quad 92.9$ grs., or 36.57 per cent. Remaining in the phials . . $161.1 \mathrm{grrs}$., or 63.43 per cent.

$$
\overline{254.0} \quad \overline{100 \cdot 00}
$$

Rather more than one-third of the salts has therefore been transferred from the solution phials to the water-jars by diffusion.

Of the diffused salts in the tumblers, $46.5 \mathrm{grs}$. were found to contain $1.90 \mathrm{gr}$. magnesia, or 4.09 per cent. Hence we have the following result:-

Magnesia originally in salts of sea-water . 6.01 per cent. Magnesia in salts diffused from sea-water . 4.09 per cent.

The magnesia, also, must in consequence be relatively concentrated in the liquid remaining behind in the diffusion cells.

$A$ probable explanation may be drawn from the last results of the remarkable discordance in the analysis of the waters of the Dead Sea, made by different chemists of eminence. I refer to the relative proportion of the salts, and not their absolute quantity, the last necessarily varying with the state of dilution of the saline water when taken up. The lake in question falls in level 10 or 12 feet every year, by evaporation. A sheet of fresh water of that depth is thrown over the lake in the wet season, which water may be supposed to flow over a fluid nearly 1.2 in density, without greatly disturbing it. The salts rise from below into the superior stratum by the diffusive process, which will bring up salts of the alkalies with more rapidity than sults of the earth, and chlorides, of either class, more rapidly than sulphates. The composition of water near the surface must therefore vary greatly, as this process is more or less advanced.

(4.) I may be allowed to add another experiment which is curious for the protracted immobility of a column of water which it exhibits, as well as for the separation occurring, which last may be interesting also in a geological point of view. $\mathbf{A}$ plain glass cylinder with a foot, 11 inches in height, and of which the capacity was 64 cubic inches, had 8 cubic inches poured into it of a saturated solution of carbonate of lime in 
carbonic acid water, containing also 200 grs. of chloride of sodium dissolved. Distilled water was then carefully poured over the saline solution, so as to fill up the jar, a float being used and the liquid disturbed as little as possible in the operation. The mouth of the jar was lastly closed by a ground glass plate, and it was left undisturbed upon the mantel-piece of a room without a fire, from March 20 to September 24 of the present year, or for six months and four days. Afterwards, on removing the cover, the fluid was observed not to have evaporated sensibly, and it exhibited no visible deposit. This I was not surprised at, as no deposit appeared in a similar experiment with the jar uncovered, after the lapse of six weeks. The liquid in the former jar was now carefully drawn off by a small siphon with the extremity of both its limbs recurved so as to open upwards, in four equal portions, which may be numbered from above downwards. Equal quantities of the four strata of liquids gave the following proportions of chloride of sodium and carbonate of lime:-

$\begin{array}{lcc} & \text { Chloride of sodium. } & \text { Carbonate of lime. } \\ \text { No. 1. } & 21.91 & 0.10 \\ \text { No. 2. } & 23.41 & 0.22 \\ \text { No. 3. } & 23.55 & 0.38 \\ \text { No. 4. } & 23.99 & 0.42\end{array}$

The diffusion of the chloride of sodium has therefore not yet reached complete uniformity, although approaching it, the proportion of that salt obtained from the top and bottom strata being as 11 to 12 . But the diffusion of the carbonate of lime appear's much less advanced, the proportion of that substance being as 1 to 4 at the top and bottom of the liquid column. The slight difference in density of the strata, it may be further remarked, must have been sufficient to preserve such a column of liquid entirely quiescent, as shown by the distribution of the carbonate of lime, during the considerable changes of temperature of the season.

Chemical analysis, which gives with accuracy the proportions of acids and bases in a solution, furnishes no means of deciding how these acids and bases are combined, or what salts exist in solution. But it is possible that light may be thrown on the constitution of mixed salts, at least when they are of unequal diffusibility, by means of a diffusion experiment. With reference to sea-water, for instance, it has been a question in what form the magnesia exists, as chloride or as sulphate; or how much exists in the one form and how much in the other. Knowing however the different rates of diffusibility of these two salts, which is nearly chloride 2 and sul- 
phate 1 , and their relation to the diffusibility of chloride of sodium, we should be able to judge from the proportion in which the magnesia travels in company with chloride of sodium, whether it is travelling in the large proportion of chloride of magnesium, in the small proportion of sulphate of magnesia, or in the intermerliate proportion of a certain mixture of chloride and sulphate of magnesia. But here we are met by a difficulty. Do the chloride of magnesium and sulphate of magnesia necessarily pre-exist in sea-water in the proportions in which they are found to diffuse? May not the more easy diffusion of chlorides determine their formation in the diffusive act, just as evaporation determines the formation of a volatile salt-producing carbonate of ammonia, for instance, from hydrochlorate of ammonia with carbonate of lime in the same solution? We shall see immediately that liquid diffusion, as well as gaseous evaporation, can produce chemical decompositions.

\section{Decomposition of Salts by Diffusion.}

(1.) At an early period of the inquiry, a solution was diffused of bisulphate of potash, saturated at $68^{\circ}$ and of density $1 \cdot 280$, from the six-ounce phial of $1 \cdot 175$ inch aperture, into 20 ounces of water. The period of diffusion extended to fifty days. About the middle of that period, a few small crystals of sulphate of potash, amounting probably to 3 or 4 hundredths of a grain, appeared in the diffusion cell and never afterwards dissolved away. When terminated, the liquid remaining in the solution cell was found of density 1.154 ; that in the water-jar 1.0326. A portion of the latter liquid gave by analysis-

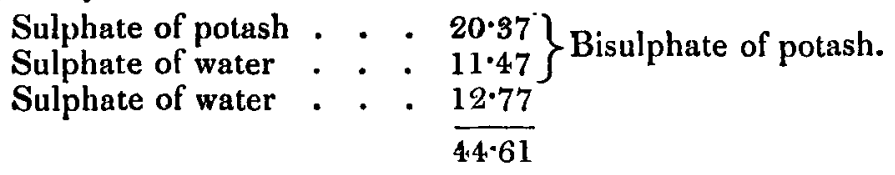

It thus appears that the bisulphate of potash undergoes decomposition in diffusing, and that the acid diffuses away to about double the extent, in equivalents, of the sulphate of potash. This greater escape of the acid will also account for the deposition of crystals of the neutral sulphate in the solution cell.

(2.) A similar experiment was made with another double sulphate of greater stability, common potash-alum. The solution of 4 anhydrous alum in 100 water, was diffused from the six-ounce phial into 24 ounces of water, at $64^{\circ} \cdot 2$, for eight days. The quantity of salt diffused in that time amounted only to $7.4 .8 \mathrm{grs}$. It contained $1.06 \mathrm{gr}$. alumina, which is Phil. Mag.S. 3. Vol. 37. No. 250. Oct. 1850. 
equivalent to $5.33 \mathrm{grs}$. of alum. The diffused salt gave off no acid vapours at $600^{\circ}$. We may therefore suppose the excess of salt which is diffused to be sulphate of potash. The diffusion product of alum, at $64^{\circ}$, appears to be-

$$
\begin{aligned}
& \text { Alum . . . . . . } 5.33 \quad 71 \cdot 26 \\
& \text { Sulphate of potash } \cdot \frac{2 \cdot 15}{7 \cdot 48} \quad \frac{28 \cdot 74}{100 \cdot 00}
\end{aligned}
$$

In a second experiment, the diffusion product amounted to 6.39 grs., of which $0.95 \mathrm{gr}$. was alumina; and it is represented by 4.77 alum and 1.52 sulphate of potash.

In connexion with the low diffusibility of the sulphate of alumina of alum, it was found that the addition of caustic potash to the alum solution, so as to convert it into an aluminate of potash, increased the diffusibility of the alumina. The diffusion product from the 4 per cent. solution of alum so treated contained $1.62 \mathrm{gr}$. of alumina in one experiment and $1 \cdot 54$ in another.

As alum is a salt of great stability, it presents a severe test of the influence in question. The decomposition of this double salt by diffusion was further confirmed therefore in experiments made by means of the four-ounce diffusion phials of 1.25 inch aperture, and the alteration which the salt undergoes in the process more exactly ascertained. 'The experiments were made at a mean temperature of $57^{\circ} \cdot 9$, and lasted seven days; the solution employed being of anhydrous alum to 100 water, as before.

In three experiments, the salt diffused out amounted to $5 \cdot 73,5.80$ and 5.65 grs.; of which the mean is 5.73 grs. The latter quantity gave 0.82 alumina and 3.22 sulphuric acid, which correspond to $4 \cdot 11$ anhydrous alum and $1 \cdot 62$ neutral sulphate of potash. Or, we have as the diffusion product of alum, in 100 parts-

$$
\begin{aligned}
& \text { Alum } \\
& \text { Sulphate of potash } \cdot \cdot \cdot \cdot \cdot \frac{71 \cdot 73}{28.27} \\
& \hline 100 \cdot 00
\end{aligned}
$$

This analysis corresponds closely with the diffusion product of the former experiments, which gave 71.26 per cent. of alum. The solution of alum which remains behind in the solution phials must of course acquire an excess of sulphate of alumina.

The salt, sulphate of alumina, did not appear to be decomposed when diffused alone. $A$ four per cent. solution of the hydrated sulphate of alumina, which is manufactured at Newcastle, when diffused in the same circumstances as the preceding solutions of alum, gave $3.40 \mathrm{grs}$. of anhydrous sulphate of alumina, in which the acid was to the alumina as 2.95 equivalents of the former to 1 equivalent of the latter, or as nearly 
as possible in the proportion of 3 equivalents of acid to 1 of base. As the Newcastle salt contained almost exactly half its weight of water, the 3.40 grs. of anhydrous salt diffused out are equivalent to $6.80 \mathrm{grs}$. of hydrated sulphate of alumina. The sulphate of alumina appears thus to be more diffusive than the double sulphate of alumina and potash, in the proportion of 6.80 to 5.73 .

(3.) It was interesting to observe what really diffuses from the ammoniated sulphate of copper $\left(\mathrm{CuO}, \mathrm{SO}^{3}, 2 \mathrm{NH}^{3}+\mathrm{HO}\right)$, and to find if the low diffusibility of that salt is attended with decomposition. The diffusion of the ammoniated sulphate of copper was therefore repeated from a 4 per cent. solution in the six-ounce solution phial, for eight days, at $64^{\circ} \cdot 2$ In evaporating the water of the jar afterwards, the ammoniated sulphate of copper present was necessarily decomposed, by the escape of ammonia, and a subsulphate of copper precipitated. The copper found, however, was estimated as neutral sulphate of copper. The diffusion product of two experiments may be represented as follows, in grains:-

$$
\begin{aligned}
& \begin{array}{cccc}
\text { Sulphate of copper. . . . } & \text { I. } & \text { II. } \\
\text {. } & 0.81 & 0.97
\end{array} \\
& \text { Sulphate of ammonia } \cdot \frac{5.46}{6.27} \quad \frac{5.53}{6.50}
\end{aligned}
$$

The abundant formation and separation of sulphate of ammonia in these experiments, prove that the ammoniated sulphate of copper is largely decomposed in diffusion.

(4.) Perhaps the most interesting result of this kind is a solution which is given of the problem of the decomposition of the alkaline sulphates by means of lime.

Solutions were prepared of $\frac{1}{2}$ per cent. of sulphate of potash and of chlorides of potassium and sodium in lime-water. Two solution phials were filled with each of these solutions, and placed for diffusion in water-jars filled with lime-water, at $49^{\circ}$, for seven days.

In the sulphate no deposition of crystallized sulphate of lime took place within the solution phial, while the waterjar acquired an alkaline reaction, which remained after precipitating the lime entirely by carbonic acid gas and evaporating twice to dryness. Hydrate of potash, it will afterwards appear, is an eminently diffusive salt, having double the diffusibility of sulphate of potash. The tendency of the former to diffuse enables the affinity of the lime for sulphuric acid to prevail, and the alkali is liberated and diffused away into the external atmosphere of lime-water. By the latter, hydrate of lime is returned to the solution cell and the decomposition continued. The salt diffused in the two cells amounted to 2.60 grs., of which 0.62 gr., or 23.85 per cent., was hydrate 
of potash. The chlorides of potassium and sodium, on the contrary, were not sensibly decomposed.

It is known that a precipitation of sulphate of lime may occur, with a larger proportion of sulphate of potash in limewater, in a close phial without external diffusion. As the decomposition of the sulphate of potash, in the latter case, has been referred to the insolubility of the sulphate of lime, so the decomposition in the former circumstances is referred, in a similar sense, to the high diffusibility of hydrate of potash.

\section{Diffusion of' Double Salts.}

How is the diffusion of two salts affected by their condition of combination as a double salt? A solution of the double sulphate of magnesia and potash, in the proportion of 100 water to 4 anhydrous salt, was operated upon in the fourounce diffusion phials of 1.25 inch aperture, with a period of diffusion of seven days, at $57^{\circ} \cdot 9 \mathrm{~F}$. The diffusion product of the double salt was 8.09 and 7.81 grs. in two experiments : mean, $7 \cdot 95$ grs.

The constituent salts, sulphate of magnesia and sulphate of potash, were now dissolved separately, in the proportions in which they existed in the double salt, namely, $1.65 \mathrm{gr}$. anhydrous sulphate of magnesia in 100 water, and 2.35 grs. sulphate of potash in 100 water, making up together 4 parts of salts. The two solutions thus contain equivalent quantities of the different sulphates.

The separate diffusion of the sulphate of magnesia was $2 \cdot 09$, 2.11 and 2.40 grs. in three cells; and of the sulphate of potash, 5.83, 5.97 and 5.54 grs. in three cells; the circumstances of the experiments being the same as those of the double salt. The means of the two salts are $2 \cdot 20$ and $5 \cdot 78$ grs.; and the sum of the two means $7.98 \mathrm{grs}$. The result is, that the separate diffusion of the constituent salts is almost identical with their diffusion when combined as a double salt:-

Diffusion of the double sulphate of magnesia and potash Diffusion of equivalents of sulphate of magnesia and sulphate of potash in separate cells. $.07 .98 \mathrm{grs}$.

It would thus appear that the diffusibility of this double salt is the sum of the separate diffusions of its constituent salts.

It has been a question whether a double salt is formed at once when its constituent salts are dissolved together, or not till the act of crystallization of the compound salt. Equivalents of the same two sulphates, making up 4 parts, were dissolved together without heat in 100 water. Now the diffusion from this mixture, which has the composition of the preceding 
solution of the double salt, exhibited notwithstanding a sensibly different result of diffusion, giving $7 \cdot 28,7 \cdot 37$ and $7 \cdot 26$ grs. in three cells; mean, $7 \cdot 30$ grs. The diffusion of the double salt was greater, namely, 795 grs. Hence a strong presumption that the mixed salts last diffused were not combined, and that the double sulphate of magnesia and potash is not necessarily formed immediately upon dissolving together its constituent salts.

In early experiments of a similar nature made upon the double salt, sulphate of copper and potash, and upon a mixof the two sulphates newly dissolved together, a similar result was obtained. While the diffusion of the mixed salts was 25.6 grs., that of the same weight of the combined salts (the double sulphate) was 30 grs. The double salt appears more diffusible, in both cases, than its mixed constituents.

These double salts appear to dissolve in water without decomposition, although the single salts may meet in solution without combining. Hence in a mixture of salts we may have more than one state of equilibrium possible. And when a salt, like alum, happens to be dissolved in such a way as to decompose it, the constituents are not necessarily reunited by subsequent mixing. Many practices in the chemical arts, which seem empirical, have their foundation possibly in facts of this kind.

\section{Diffusion of one Salt into the Solution of another Salt.}

It was curious and peculiarly important, in reference to the relation of liquid to gaseous diffusion, to find whether one salt $A$ would diffuse into water already charged with an equal or greater quantity of another salt $\mathrm{B}$, as a gas $a$ freely diffuses into the space already occupied by another gas $b$; the gas $b$ in return diffusing at the same time into the space occupied by $a$. Or whether, on the contrary, the diffusion of the salt $A$ is resisted by $B$. The latter result would indicate a neutralization of the water's attraction, and a kind of equivalency or equality of power and exchangeability of different salts, in respect of that effect, which would divide entirely the phænomena of liquid from those of gaseous diffusion.

(1.) A solution of 4 parts of carbonate of soda to 100 water, of density 1.0406, was placed in the six-ounce diffusion phial of 1.175 inch aperture, and allowed to communicate with 24 ounces of water.

Two similar diffusion phials, equally charged, were immersed in 24 ounces of a solution of 4 parts of chloride of sodium to 100 water, having the density 1.0282. The diffusion proceeded for eight days, in all cases, at $64^{\circ}$. The proportion of carbonate of soda found without in the water-jar 
afterwards, was ascertained by an alkalimetrical process, the neutralization being effected at the boiling-point. The following are the results :-

Experiment I. Diffusion product $\} 9.06 \mathrm{grs}$. of carbonate of into water ...... $\}$ soda.

Experiment II. Diffusion product 8.82 grs. of carbonate of into solution of chloride of sodium $\}$ soda.

Experiment III. Diffusion product $\{9 \cdot 10$ grs. of carbonate of into solution of chloride of sodium $\}$ soda.

It thus appears that per cent. of chloride of sodium present in the water atmosphere of the jar has no sensible effect in retarding the diffusion into it, from the solution cell, of carbonate of soda from a solution containing also 4 per cent. of the latter.

(2.) The experiment was varied by allowing the solution of carbonate of soda to diffuse into a solution of sulphate of soda, a salt more similar to the former in solubility and composition. The solution of the latter, containing 4 per cent., was of density $1 \cdot 0352$. The temperature and period of diffusion were the same as before:-

Experiment IV. Diffusion product $77 \cdot 84$ grs. of carbonate of into solution of sulphate of soda $\}$ soda.

Experiment V. Diffusion product $\{7.82$ grs. of carbonate of into solution of sulphate of soda $\}$ soda.

Here we find a small reduction in the quantity of carbonate of soda diffused, amounting to one-eighth of the whole. The sulphate of soda has therefore exercised a positive interference in checking the diffusion of the carbonate to that extent. So small and disproportionate an effect however is scarcely sufficient to establish the existence of a mutual elasticity and resistance between these two salts.

Still it might be said, may not the diffusion of one salt be resisted by another salt which is strictly isomorphous with the first?

(3.) A solution of 4 parts of nitrate of potash to 100 of water, of density 1.0241, placed in the solution phial, was allowed to communicate with water containing 4 per cent. of nitrate of ammonia in the water-jar, which last solution was of density 1.0136; with all other circumstances as before. With one solution phial having the usual aperture, 1.175 inch, the diffusion product was 15.32 grs. of nitrate of potash. With a second phial, having a larger aperture of $1 \cdot 190$ inch, the diffusion product was 18.03 grs. of nitrate of potash. No comparative experiment, on the diffusion of nitrate of potash into water, was made at the same time. But nitrate of ammonia, which appeared before to coincide in diffusibility with 
nitrate of potash, gave on a former occasion, in similar circumstances, and at $64^{\circ} \cdot 9$, nearly the same temperature, a diffusion product of $15.80 \mathrm{grs}$. 'The quantity of nitrate of potash (15.32 grs.) which diffused into the solution of nitrate of ammonia approaches so closely to the number quoted, that we may safely conclude that the diffusion of nitrate of potash is not sensibly resisted by nitrate of anmonia, although these two salts are closely isomorphous. They are still therefore inelastic to each other, like two different gases.

These experiments have been made upon dilute solutions, and it is not at all impossible that the result may be greatly modified in concentrated solutions of the same salts, or when the solutions approach to saturation. But there is reason to apprehend that the phænomena of liquid diffusion are exhibited in the simplest form by dilute solutions, and that concentration of the dissolved salt, like compression of a gas, is attended often with a departure from the normal character.

On approaching the degree of pressure which occasions the liquefaction of a gas, an attraction appears to be brought into play, which impairs the elasticity of the gas; so on approaching the point of saturation of a salt, an attraction of the salt molecules for each other, tending to produce crystallization, comes into action, which will interfere with and diminish that elasticity or dispersive tendency of the dissolved salt which occasions its diffusion.

We are perhaps justified in extending the analogy a step further between the characters of a gas near its point of liquefaction and the conditions which we may assign to solutions. The theoretical density of a liquefiable gas may be completely disguised under great pressure. Thus, under a reduction by pressure of 20 volumes into 1 , while the elasticity of air is 19.72 atmospheres, that of carbonic acid is only 16.70 atmospheres, and the deviation from their normal densities is in the inverse proportion. Of salts in solution the densities may be affected by similar causes, so that although different salts in solution really admit of certain normal relations in density, these relations may be concealed and not directly observable.

The analogy of liquid diffusion to gaseous diffusion and vaporization is borne out in every character of the former which has been examined. Mixed salts appear to diffuse independently of each other, like mixed gases, and into a water atmosphere already charged with another salt as into pure water. Salts also are unequally diffusible, like the gases, and separations, both mechanical and chemical (decompositions), are produced by liquid as well as by gaesous diffusion. But it still remains to be found whether the diffusibilities of different salts are in any fixed proportion to each other, as simple. 
numerical relations are known to prevail in the diffusion velocities of the gases, from which their densities are deducible.

It was desirable to make numerous simultaneous observations on the salts compared, in order to secure uniformity of conditions, particularly of temperature. The means of greatly multiplying the experiments were obtained by having the solution phial cast in a mould, so that any number of solution cells could be procured of the same form and dimensions. The phials were of the form represented (fig. 3), Fig. 3. holding about 4 ounces, or more nearly $2080 \mathrm{grs}$. of water to the base of the neck, and the mouths of all were ground down, so as to give the phial a uniform height of 3.8 inches. The mouth or neck was also ground to fit a gauge-stopper of wood, which was 0.5 inch deep and slightly conical, being 1.24 inch in diameter on the upper, and 1.20 inch on the lower surface. These are therefore the dimensions of the diffusion aperture of the new solution cells. A little

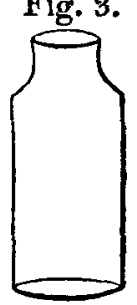
contrivance to be used in filling the phials to a constant distance of half an inch from the surface of the lip, proved useful. It was a narrow slip of brass plate, having a descending pin of exactly half an inch in length fixed on one side of it (fig. 4). This being laid across the mouth of the phial with the pin downwards in the neck, the solution was poured into the phial till it reached the point of the pin. The brass plate and pin being removed, Fig. 4. the neck was then filled up with distilled water, with the aid of the little float as before described. The water-jar, in which the solution phial stood, was filled up with water also as formerly, so as to cover the phial entirely to the depth of 1 inch. This water atmosphere amounted to 8750 grs., or about 20 ounces. $A$ glass plate was placed upon the mouth of the water-jar itself to prevent evaporation. Sometimes 80 or 100 diffusion cells were put in action at the same time. The period of diffusion chosen was now always exactly seven days, unless otherwise mentioned.

\section{Diffusion of Salts of Potash and Ammonia.}

Solutions were prepared of the various salts, in a pure state,

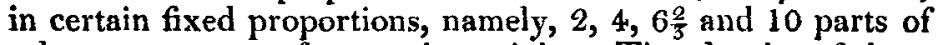
salt to 100 parts of water by weight. The density of these solutions was observed by the weighing-bottle, at $60^{\circ}$. The solutions were frequently diffused at two different tempera- 
tures; one, the temperature of the atmosphere, which was fortunately remarkably constant during most of the experiments to be recorded at present, and the other, a lower temperature, obtained in a close box of large dimensions, containing masses of ice. The results at the artificial temperature were obviously less accurate than those of the natural temperature, but have still considerable value. Three experiments were generally made upon the diffusion of each solution at the higher, with two experiments at the lower temperature.

(1.) The carbonate and sulphate of potash and sulphate of ammonia were first diffused during a period of seven days, of which the temperatures observed by a thermometer placed near the water-jars were $64^{\circ} \cdot 5,65^{\circ}, 63^{\circ} \cdot 5,63^{\circ}, 63^{\circ}, 63^{\circ} \cdot 5,65^{\circ}$ and $66^{\circ}$; mean temperature $64^{\circ} \cdot 2$.

Table VII.--Diffusion of Carbonate of Potash, Sulphate of Potash and Sulphate of Ammonia.

\begin{tabular}{|c|c|c|c|c|c|}
\hline \multirow{2}{*}{ Parts of anhydrous salt to 100 water. } & \multirow{2}{*}{$\begin{array}{c}\text { Density of } \\
\text { solution at } \\
60^{\circ} .\end{array}$} & \multicolumn{2}{|c|}{ At $64^{\circ} \cdot 2$. } & \multicolumn{2}{|c|}{ At $37^{\circ} \cdot 6$. } \\
\hline & & $\begin{array}{l}\text { Experi- } \\
\text { ments. }\end{array}$ & Mean. & \begin{tabular}{|} 
Experi- \\
ments.
\end{tabular} & Mean. \\
\hline $\begin{array}{c}\text { Carbonate of potash. } \\
\qquad \begin{array}{c}2 \\
4 \\
6 \frac{2}{8} \\
10\end{array}\end{array}$ & $\begin{array}{r}1.0178 \\
1.0347 \\
1.0572 \\
1.0824\end{array}$ & $\begin{array}{r}5 \cdot 36 \\
5 \cdot 55 \\
10 \cdot 39 \\
10 \cdot 11 \\
16 \cdot 50 \\
16 \cdot 46 \\
17 \cdot 05 \\
24 \cdot 42 \\
24 \cdot 94 \\
24 \cdot 70\end{array}$ & $\begin{array}{r}5 \cdot 45 \\
10 \cdot 25 \\
16 \cdot 67 \\
24 \cdot 69\end{array}$ & $\begin{array}{r}3 \cdot 80 \\
3 \cdot 91 \\
6 \cdot 99 \\
7 \cdot 19 \\
11 \cdot 42 \\
11 \cdot 08\end{array}$ & $\begin{array}{r}3.85 \\
7.09 \\
11.25\end{array}$ \\
\hline $\begin{array}{l}\text { Sulphate of potash. } \\
\begin{array}{c}2 \\
4 \\
63 \\
10\end{array}\end{array}$ & $\begin{array}{r}1.0155 \\
1.0318 \\
1.0512 \\
1.0742\end{array}$ & $\begin{array}{r}5 \cdot 62 \\
5 \cdot 42 \\
10 \cdot 49 \\
10 \cdot 65 \\
17 \cdot 07 \\
16 \cdot 89 \\
17 \cdot 54 \\
23 \cdot 40 \\
23 \cdot 59 \\
23 \cdot 88\end{array}$ & $\begin{array}{r}5 \cdot 52 \\
10 \cdot 57 \\
17 \cdot 17 \\
23 \cdot 62\end{array}$ & $\begin{array}{r}3 \cdot 93 \\
3 \cdot 98 \\
7 \cdot 50 \\
7 \cdot 31 \\
11 \cdot 62 \\
11 \cdot 71\end{array}$ & $\begin{array}{r}3.95 \\
7 \cdot 40 \\
11.66\end{array}$ \\
\hline $\begin{array}{c}\text { Sulphate of ammonia, } \mathrm{NH}^{4} \mathrm{O}, \mathrm{SO}^{5} \text {. } \\
2 \\
4 \\
6 \frac{2}{3} \\
10\end{array}$ & $\begin{array}{r}1 \cdot 0117 \\
1 \cdot 0229 \\
1 \cdot 0369 \\
1 \cdot 0529\end{array}$ & $\begin{array}{r}5 \cdot 71 \\
5 \cdot 45 \\
10 \cdot 72 \\
10 \cdot 30 \\
17 \cdot 28 \\
16 \cdot 28 \\
16 \cdot 80 \\
21 \cdot 86 \\
22 \cdot 49 \\
22 \cdot 25\end{array}$ & $\begin{array}{r}5 \cdot 58 \\
10 \cdot 51 \\
16 \cdot 79 \\
22 \cdot 20\end{array}$ & $\begin{array}{r}3 \cdot 73 \\
3 \cdot 79 \\
7 \cdot 54 \\
7 \cdot 86 \\
10 \cdot 94 \\
10 \cdot 98\end{array}$ & $\begin{array}{r}3.76 \\
7 \cdot 70 \\
10 \cdot 96\end{array}$ \\
\hline
\end{tabular}


The diffusion product was obtained by evaporating the water of each jar separately as before, and the result is expressed in grains.

It will be observed at once, on comparing the means of the experiments, that the three salts under consideration are remarkably similar in their diffusion, particularly with the smaller proportions of salt. Thus the mean diffusion of the $2,4,6 \frac{2}{5}$ and 10 parts of the salts is as follows:-

Diffusion at $64^{\circ} \cdot 2$.

\begin{tabular}{|c|c|c|c|c|}
\hline & 2. & 4. & $6 \frac{2}{3}$. & 10. \\
\hline Carbonate of potash ... & $\mathbf{5 . 4 5}$ & $\mathbf{1 0 . 2 5}$ & $\mathbf{1 6 . 6 7}$ & $\mathbf{2 4 . 6 9}$ \\
Sulphate of potash ..... & $\mathbf{5 . 5 2}$ & $\mathbf{1 0 . 5 7}$ & $17 \cdot 17$ & $\mathbf{2 3 . 6 2}$ \\
Sulphate of ammonia ... & $\mathbf{5 . 5 8}$ & $\mathbf{1 0 . 5 1}$ & $\mathbf{1 6 . 7 9}$ & $\mathbf{2 2 . 2 0}$ \\
\hline
\end{tabular}

Diffusion at $37^{\circ} \cdot 6$.

\begin{tabular}{|c|c|c|c|}
\hline & 2. & 4. & $6 \frac{2}{3}$ \\
\hline 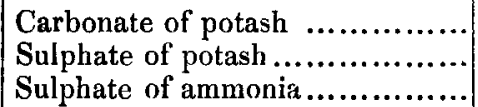 & $\begin{array}{l}3 \cdot 85 \\
3 \cdot 95 \\
3 \cdot 76\end{array}$ & $\begin{array}{l}7 \cdot 09 \\
7 \cdot 40 \\
7 \cdot 70\end{array}$ & $\begin{array}{l}11 \cdot 25 \\
11 \cdot 66 \\
10 \cdot 96\end{array}$ \\
\hline
\end{tabular}

The proportions diffused are sensibly equal, of the different salts, at the higher temperature, with the exception of the largest proportion of salt, 10 per cent., when a certain divergence occurs. This last fact is consistent with our expectations, that the diffusion of salts would prove most highly normal in dilute solutions. Some of the irregularities at the lower temperature are evidently of an accidental kind.

(2.) The neutral chromate and acetate of potash were diffused at a temperature ranging from $63^{\circ}$ to $65^{\circ}$, or at a mean temperature of $64^{\circ} \cdot 1$, which almost coincides with the higher temperature of the last experiments. 
Prof. Graham on the Difficsion of Liquids.

Table VIII.-Diffusion of Chromate of Potash and Acetate of Potash, at $64^{\circ} \cdot 1$.

\begin{tabular}{|c|c|c|c|}
\hline $\begin{array}{l}\text { Parts of anhydrous salt } \\
\text { to } 100 \text { water. }\end{array}$ & $\begin{array}{c}\text { Density of } \\
\text { solution at } 60^{\circ}\end{array}$ & Experiments. & Mean. \\
\hline $\begin{array}{l}\text { Chromate of potash. } \\
2 \\
4 \\
6 \frac{2}{3} \\
10\end{array}$ & $\begin{array}{l}1 \cdot 0158 \\
1 \cdot 0313 \\
1 \cdot 0512 \\
1 \cdot 0750\end{array}$ & $\begin{array}{r}5 \cdot 79 \\
5 \cdot 66 \\
5 \cdot 86 \\
11 \cdot 10 \\
11 \cdot 35 \\
11 \cdot 13 \\
17 \cdot 76 \\
17 \cdot 72 \\
17 \cdot 32 \\
24 \cdot 49 \\
24 \cdot 92 \\
24 \cdot 85\end{array}$ & $\begin{array}{r}5 \cdot 77 \\
11 \cdot 19 \\
17 \cdot 60 \\
24 \cdot 75\end{array}$ \\
\hline 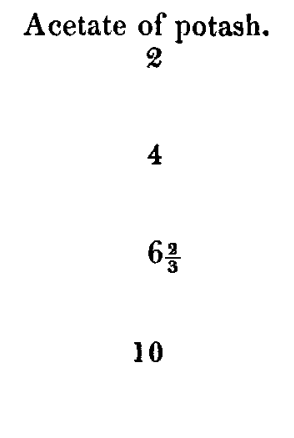 & $\begin{array}{l}1 \cdot 0095 \\
1 \cdot 0184 \\
1 \cdot 0306 \\
1 \cdot 0447\end{array}$ & $\begin{array}{r}5 \cdot 93 \\
5 \cdot 75 \\
5 \cdot 88 \\
10 \cdot 55 \\
10 \cdot 56 \\
10 \cdot 98 \\
16 \cdot 53 \\
16 \cdot 06 \\
16 \cdot 84 \\
24 \cdot 27 \\
24 \cdot 82 \\
25 \cdot 46\end{array}$ & $\begin{array}{r}5 \cdot 85 \\
10 \cdot 70 \\
16 \cdot 48 \\
24 \cdot 85\end{array}$ \\
\hline
\end{tabular}

We have the same close correspondence in the diffusion products of these two salts as in the preceding group, and here the correspondence extends to the 10 per cent. solution.

Diffusion at $64^{\circ} \cdot 1$.

\begin{tabular}{|l|c|c|c|c|}
\hline & 2. & 4. & $6 \frac{2}{3}$. & 10. \\
\hline Chromate of potash $\ldots .$. & $5 \cdot 77$ & $11 \cdot 19$ & $17 \cdot 60$ & $24 \cdot 75$ \\
Acetate of potash ...... & $5 \cdot 85$ & $10 \cdot 70$ & $16 \cdot 48$ & 24.85 \\
\hline
\end{tabular}

The 10 per cent. solution of these two salts also agrees with the same solution of carbonate of potash, which was $24 \cdot 69 \mathrm{grs}$. Nor do the lower proportions diverge greatly from the preceding group of salts. 
(3.) Another pair of salts were simultaneously diffused, but with an accidental difference of $0^{\circ} \cdot 4$ of temperature.

Table IX.-Diffusion of Bicarbonate of Potash, $\mathrm{KO}, \mathrm{CO}^{2}$ $+\mathrm{HO}, \mathrm{CO}^{2}$, at $64^{\circ} \cdot 1$, and Bichromate of Potash, $\mathrm{KO}, 2 \mathrm{CrO}^{3}$, at $64^{\circ} \cdot 5$.

\begin{tabular}{|c|c|c|c|}
\hline \multirow{2}{*}{$\begin{array}{l}\text { Parts of anhydrous salt to } 100 \\
\text { water. }\end{array}$} & \multirow{2}{*}{$\begin{array}{c}\text { Density of } \\
\text { solution at } 60^{\circ} \text {. }\end{array}$} & \multicolumn{2}{|c|}{ At $64^{0.1} 1$ and $64^{\circ .5}$} \\
\hline & & Experiments. & Mean. \\
\hline $\begin{array}{c}\text { Bicarbonate of potash. } \\
\mathbf{2} \\
4\end{array}$ & $\begin{array}{r}1.0129 \\
1.0252\end{array}$ & $\begin{array}{r}5 \cdot 74 \\
5 \cdot 77 \\
5 \cdot 91 \\
10 \cdot 75 \\
11 \cdot 16 \\
11 \cdot 13\end{array}$ & $\begin{array}{r}5 \cdot 81 \\
11 \cdot 01\end{array}$ \\
\hline $\begin{array}{c}\text { Bichromate of potash. } \\
2 \\
4\end{array}$ & $\begin{array}{l}1.0139 \\
1.0273\end{array}$ & $\begin{array}{r}5 \cdot 64 \\
5 \cdot 73 \\
5 \cdot 59 \\
11 \cdot 55 \\
11 \cdot 54 \\
11 \cdot 39\end{array}$ & $\begin{array}{r}5 \cdot 65 \\
11 \cdot 49\end{array}$ \\
\hline
\end{tabular}

Here again the two salts approach closely in diffusion, and also correspond well with the two preceding series.

Mean Diffusion at $64^{\circ} \cdot 1$ and $64^{\circ} \cdot 5$.

\begin{tabular}{|c|c|c|}
\hline & 2. & 4. \\
\hline $\begin{array}{l}\text { Bicarbonate of potash } \ldots \ldots \ldots . . \\
\text { Bichromate of potash } \ldots \ldots \ldots \ldots\end{array}$ & $\begin{array}{l}5 \cdot 81 \\
5 \cdot 65\end{array}$ & $\begin{array}{l}11 \cdot 01 \\
11 \cdot 49\end{array}$ \\
\hline
\end{tabular}

It is singular to find that salts differing so much in constitution and atomic weight as the chromate and bichromate of potash, may be confounded in diffusibility. The diffusion products of these two salts are, for the 2 per cent. solutions, 5.77 and 5.65 grs., and for the 4 per cent. solution, 11.19 and 11.49 grs. The bicarbonate of potash also exhibits a considerable analogy to the carbonate, but resembles still more closely the acetate. It is thus obvious that equality, or similarity, of diffusion is not confined to the isomorphous groups of salts.

(4.) The nitrates of potash and ammonia have already appeared to be equidiffusive at two different temperatures. They were diffused again in the same proportions as the last salts, at a temperature varying from $63^{\circ}$ to $67^{\circ} \cdot 5$. 
Prof. Graham on the Diffusion of Liquids.

Table X.-Diffusion of Nitrate of Potash and Nitrate of Ammonia at $65^{\circ} \cdot 9$.

\begin{tabular}{|c|c|c|c|}
\hline $\begin{array}{l}\text { Parts of anhydrous salt to } 100 \\
\text { water. }\end{array}$ & $\begin{array}{l}\text { Density of solu- } \\
\text { tion at } 60^{\circ} \text {. }\end{array}$ & Experiments. & Mean. \\
\hline $\begin{array}{l}\text { Nitrate of potash. } \\
\begin{array}{c}2 \\
4 \\
6 \frac{2}{3} \\
10\end{array}\end{array}$ & $\begin{array}{r}1 \cdot 0123 \\
1 \cdot 0243 \\
1 \cdot 0393 \\
1 \cdot 0581\end{array}$ & $\begin{array}{r}7 \cdot 34 \\
7 \cdot 58 \\
7 \cdot 49 \\
13 \cdot 66 \\
14 \cdot 24 \\
14 \cdot 02 \\
22 \cdot 11 \\
22 \cdot 94 \\
22 \cdot 05 \\
32 \cdot 06 \\
32 \cdot 90 \\
32 \cdot 50\end{array}$ & $\begin{array}{r}7 \cdot 47 \\
13 \cdot 97 \\
22 \cdot 37 \\
32 \cdot 49\end{array}$ \\
\hline $\begin{array}{c}\text { Nitrate of ammonia } \mathrm{NH}^{4} \mathrm{O}, \mathrm{NO}^{5} \\
4 \\
6 \frac{2}{3} \\
10\end{array}$ & $\begin{array}{l}1 \cdot 0080 \\
1 \cdot 0154 \\
1 \cdot 0256 \\
1 \cdot 0375\end{array}$ & $\begin{array}{r}7 \cdot 85 \\
7 \cdot 71 \\
7 \cdot 64 \\
14 \cdot 20 \\
14 \cdot 79 \\
14 \cdot 45 \\
23 \cdot 66 \\
23 \cdot 35 \\
22 \cdot 22 \\
34 \cdot 94 \\
33 \cdot 49 \\
34 \cdot 23\end{array}$ & $\begin{array}{r}7 \cdot 73 \\
14 \cdot 48 \\
22 \cdot 74 \\
34 \cdot 22 \\
\end{array}$ \\
\hline
\end{tabular}

The solution of nitrate of ammonia of the water-jars was evaporated carefully al a temperature not exceeding $120^{\circ} \mathrm{F}$., to prevent loss of the salt by sublimation or decomposition.

Diffusion at $65^{\circ} \cdot 9$.

\begin{tabular}{|c|c|c|c|c|}
\hline & 2. & 4. & $6 \frac{2}{3}$. & 10. \\
\hline 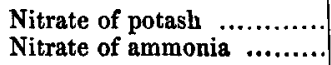 & $\begin{array}{l}7 \cdot 47 \\
7 \cdot 73\end{array}$ & $\begin{array}{l}13 \cdot 97 \\
14 \cdot 48\end{array}$ & $\begin{array}{l}\mathbf{2 2 \cdot 3 7} \\
\mathbf{2 2 \cdot 7 4}\end{array}$ & $\begin{array}{l}\mathbf{3 2 \cdot 4 9} \\
\mathbf{3 4} \cdot \mathbf{2 2}\end{array}$ \\
\hline
\end{tabular}

Although these salts correspond closely, it is probable that neither the diffusion of these nor the diffusion of any others is absolutely identical. The nitrate of ammonia appears to possess a slight superiority in diffusion over the nitrate of potash, which increases with the large proportions of salt in solution. They are both considerably more diffusible than the seven preceding salts.

(5.) A second pair of isomorphous salts were compared, the chlorides of potassium and ammonium. 
Table XI._Diffusion of Chloride of Potassium and Chloride of Ammonium.

\begin{tabular}{|c|c|c|c|c|c|}
\hline \multirow{2}{*}{$\begin{array}{l}\text { Parts of anhydrous salt to } 100 \\
\text { water. }\end{array}$} & \multirow{2}{*}{$\begin{array}{l}\text { Density of so- } \\
\text { lution at } 60^{\circ} \text {. }\end{array}$} & \multicolumn{2}{|c|}{ At $66^{\circ} \cdot 2$. } & \multicolumn{2}{|c|}{ At $64^{\circ} \cdot 7$} \\
\hline & & $\begin{array}{l}\text { Experi- } \\
\text { ments. }\end{array}$ & Mean. & $\begin{array}{l}\text { Experi- } \\
\text { ments. }\end{array}$ & Mean. \\
\hline $\begin{array}{l}\text { Chloride of potassium. } \\
\qquad \begin{array}{c}2 \\
6 \frac{2}{3} \\
10\end{array}\end{array}$ & $\begin{array}{r}1.0127 \\
1 \cdot 0248 \\
1.0401 \\
1 \cdot 0592\end{array}$ & $\begin{array}{r}7 \cdot 83 \\
7 \cdot 72 \\
7 \cdot 55 \\
15 \cdot 22 \\
15 \cdot 59 \\
15 \cdot 07 \\
\mathbf{2 4} \cdot 88 \\
\mathbf{2 4} \cdot 64 \\
25 \cdot 09 \\
36 \cdot 23 \\
37 \cdot 63\end{array}$ & $\begin{array}{r}7 \cdot 70 \\
15 \cdot 29 \\
24 \cdot 87 \\
36 \cdot 93\end{array}$ & \begin{tabular}{r|}
$8 \cdot 03$ \\
$7 \cdot 89$ \\
$15 \cdot 21$ \\
$14 \cdot 82$ \\
$24 \cdot 83$ \\
$24 \cdot 62$
\end{tabular} & $\begin{array}{r}7 \cdot 96 \\
15 \cdot 01 \\
24 \cdot 72\end{array}$ \\
\hline $\begin{array}{c}\text { Chloride of ammonium. } \\
2 \\
4 \\
6 \frac{2}{3} \\
10\end{array}$ & $\begin{array}{l}1.0061 \\
1.0118 \\
1.0190 \\
1.0272\end{array}$ & $\begin{array}{r}7 \cdot 10 \\
8 \cdot 52 \\
14 \cdot 55 \\
14 \cdot 64 \\
24 \cdot 30 \\
36.53\end{array}$ & $\begin{array}{r}7 \cdot 81 \\
\\
14 \cdot 60 \\
24 \cdot 30 \\
\\
36 \cdot 53\end{array}$ & $\begin{array}{r}7 \cdot 10 \\
7 \cdot 24 \\
13 \cdot 91 \\
14 \cdot 91 \\
24 \cdot 12 \\
24 \cdot 13\end{array}$ & $\begin{array}{r}7 \cdot 17 \\
14 \cdot 41 \\
24 \cdot 12\end{array}$ \\
\hline
\end{tabular}

These two salts agree well in diffusibility, and are also evidently related to the preceding nitrates. The quantity of chloride of ammonium diffused was determined by evaporation, which is troublesome and may lead to small errors, from the volatility and efflorescent tendency of this salt. It would be easier and more accurate to determine this and other chlorides by the use of a normal solution of nitrate of silver, and so avoid evaporation.

Diffusion at $66^{\circ} \cdot 2$.

\begin{tabular}{|l|c|c|c|c|}
\hline & 2. & 4. & $6 \frac{2}{3}$. & 10. \\
\hline Chloride of potassium & $7 \cdot 70$ & $15 \cdot 29$ & $24 \cdot 87$ & $\mathbf{3 6 \cdot 9 3}$ \\
Chloride of ammonium & $7 \cdot 81$ & $14 \cdot 60$ & $24 \cdot 30$ & $\mathbf{3 6 \cdot 5 3}$ \\
\hline
\end{tabular}

The quantities diffused of these two chlorides are more closely in proportion to the strength of the original solution, than with any of the preceding salts of potash. Thus the quantities diffused from the 2 and 10 per cent. solutions of chloride of potassium are 7.70 and 36.93 grs., which are as 2 to $9 \cdot 6$, which is nearly as 2 to 10 . Chloride of sodium was observed before to be nearly uniform in this respect; but other salts appear to lose considerably in diffusibility with the higher 
proportions of salt. It is possibly a consequence of the crystallizing attraction, to which reference was lately made, coming into action in strong solutions and resisting diffusion

(6.) The diffusion of chlorate of potash was observed at a temperature ranging from $63^{\circ}$ to $65^{\circ}$, of which the mean was $64^{\circ} \cdot 1$.

Table XII.-Diffusion of Chlorate of Potash.

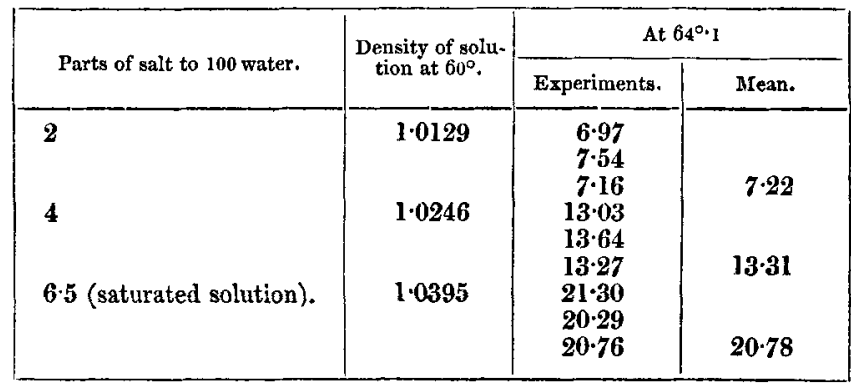

The solutions of chlorate of potash must be evaporated and the residuary salt dried at a temperature not exceeding $212^{\circ}$, otherwise a very sensible quantity of chloride of potassium may be formed. The chlorate appears to be sensibly inferior in diffusibility to the nitrate of potash. From the 4 per cent. solution of the chlorate we have a diffusion product of 13.27 grs., and from the corresponding solution of the nitrate 13.97 grs.; but the latter was obtained at a temperature $1^{0.8}$ higher than the former. It remains a question whether chlorate of potash does not really belong to the nitre group of salts, but has its diffusion interfered with by some secondary agency, such as its sparing solubility and consequent nearer approach to the saturating proportion.

It is certainly true that the uniformity of diffusion generally increases with the dilution of the solutions. This appears on comparing the diffusion of the 4 per cent. solution of what may be called the sulphate of potash group, with the diffusions of the 2 per cent. solutions of the same salts.

Diffusion of Salts of the Sulphate of Potash Class.

\begin{tabular}{|l|c|c|}
\hline & 4. & 2. \\
\hline Carbonate of potash ......... & $10 \cdot 27$ & $5 \cdot 45$ \\
Sulphate of potash ......... & $10 \cdot 57$ & $5 \cdot 52$ \\
Sulphate of ammonia......... & $10 \cdot 51$ & 5.58 \\
Acetate of potash .......... & $10 \cdot 70$ & $5 \cdot 85$ \\
Bicarbonate of potash ....... & $11 \cdot 01$ & $\mathbf{5 . 8 1}$ \\
Chromate of potash ......... & $11 \cdot 19$ & $\mathbf{5 \cdot 7 7}$ \\
Bichromate of potash ...... & $11 \cdot 49$ & $5 \cdot 65$ \\
\hline
\end{tabular}


Thus while the 4 per cent. solutions range from 10.27 to 11.49 grs., or from 100 to $111 \cdot 8$, the 2 per cent. solutions range from $5.45 \mathrm{grs}$, to $5.85 \mathrm{grs}$, or from 100 to 107.3 .

As it appeared to be in dilute solutions that the greatest uniformity of diffusion is to be expected, a series of experiments was instituted upon the preceding salts, with the addition of acetate of potash, which appeared to belong to the same class, the solution employed being that of 1 salt to 100 water. The experiments were made in a vault, of which the temperature was nearly uniform, falling in a gradual manner from $59^{\circ}$ to $58^{\circ}$, with a mean of $58^{\circ} .5$ during the period of seven days which the diffusion lasted. Eight phials of each salt were diffused, and the liquids of four water-jars evaporated together.

Carbonate of potash gave 10.42 and $10.59 \mathrm{grs}$. of salt diffused: mean 10.51 grs., or 2.63 grs. for one cell.

Sulphate of potash gave 10.72 and 10.78 grs. of salt diffused : mean $10^{\circ} 75 \mathrm{grs}$, , or $2.69 \mathrm{grs}$. for one cell.

Acetate of potash, its diffusion product being treated with an excess of hydrochloric acid, gave 8.30 and $8.04 \mathrm{grs}$. of chloride of potassium, equivalent to 10.91 and $10.57 \mathrm{grs}$. of acetate of potash; mean 10.74 grs. of acetate of potash, or $2 \cdot 68$ grs. for one cell. The diffusion of these three salts is therefore remarkably similar:-

$$
\begin{aligned}
& \text { Diffusion of } 1 \text { per cent. solutions at } 58^{\circ} \cdot 5 \text {. } \\
& \text { Carbonate of potash . . . } 2 \cdot 63 \text { grs. } \\
& \text { Sulphate of potash . . . . } 269 \text { grs. } \\
& \text { Acetate of potash . . . . } 2 \cdot 68 \mathrm{grs} \text {. }
\end{aligned}
$$

The 1 per cent. solution of neutral or yellow chromate of potash in good crystals gave 11.28 and 11.35 grs.; mean $11.31 \mathrm{grs}$., or $2.83 \mathrm{grs}$. for each cell. It was remarked of the diffused chromate in this experiment, that it contained a sensible quantity of green oxide of chromium. The diffusion of a salt appears indeed to try its tendencies to decomposition very severely.

The bicarbonate of potash gave 8.83 and 8.35 grs. of chloride of potassium, the diffusion product being neutralized with hydrochloric acid; equivalent to 11.25 and $11.21 \mathrm{grs}$. of bicarbonate of potash; mean 11.23 grs., or 2.81 grs. for one cell.

The bichromate of potash gave 11.54 and $11.49 \mathrm{grs}$. of salt diffused; mean 11.51 grs., or 2.88 grs. for one cell. These last three salts give all a larger diffusion product than the preceding three, while they agree well together. It is doubtful whether this excess in their diffusion is occasioned by a partial decomposition in the act of diffusion, which might be of 
such a kind as to increase the real or apparent diffusion in every one of them, or whether it is a peculiar character of this little group, to which the ferricyanide of potassium, it will be afterwards seen, falls to be added, while the ferrocyanide appears to belong to the other group :-

Diffusion of 1 per cent. solutions at $58^{\circ} \cdot 5$.

Chromate of potash . . . 2.83 grs.

Bicarbonate of potash . . 2.81 grs.

Bichromate of potash . . . 2.88 grs.

The divergence from each other of two salts so closely isomorphous as sulphate and chromate of potash, in the proportion of 100 to $105 \cdot 2$, is certainly remarkable, unless due to a slight decomposition of the latter.

\section{(7.) Ferrocyanide and Ferricyanide of Potassium.}

Of these two salts the 1 per cent. solution only was diffused. The time of diffusion was seven days, as usual ; the mean temperature $54^{\circ} \cdot 5$. In evaporating the liquid of the water-jars, both salts were partially decomposed, so that it became necessary to estimate the diffusion product by a determination of the potash. Eight cells were employed for one salt and six for the other, and the liquids of the water-jars evaporated two together.

The diffusion product of ferrocyanide of potassium (anhydrous) was $5 \cdot 02,5 \cdot 22,5.02$ and $5.20 \mathrm{grs}$; mean 5.12 grs., or for one cell 2.56 grs.

The diffusion product of ferricyanide of potassium was 5.54 , $5 \cdot 64$ and 5.36 grs.; mean $5 \cdot 51$ grs., or for one cell $2 \cdot 75$ grs.

Three cells of a similar solution of sulphate of potash which were diffused for seven days at a mean temperature $1^{\circ}$ lower, or of $53^{\circ} .5$, gave $2.56,2.53$ and 2.62 grs.; mean for one cell $2.57 \mathrm{grs}$., a number which almost coincides with that of the ferrocyanide of potassium (2.56 grs.). The ferricyanide of potassium, on the other hand, is sensibly more diffusive, as 107.6 to 100 , and appears to rank with the bicarbonate and bichromate of potash. The ferricyanide of potassium, again, is a salt which probably undergoes a slight decomposition in diffusion like those salts mentioned :-

\section{Diffiusion of 1 per cent. solutions.}

Sulphate of potash . . . 2.57 grs. at $53^{\circ} .5$. Ferrocyanide of potassium . . 2.56 grs. at $54^{\circ} .5$. Ferricyanide of potassium . . $2.75 \mathrm{grs}$ at 54.5 .

The salts of the nitre class may also be compared in the Phil. Mag. S. 3. Vol, 37. No. 250. Oci. 1850. 
same manner, and I shall now add a third series of results obtained from the diffusion of 1 per cent. solutions of the same salts. The temperature of diffusion of this new series was $64^{\circ} \cdot 5$. Six phials of each salt were diffused, and they were evaporated afterwards two and two. This double diffusion product, however, is divided by 2 in the table.

Diffusion of Salts of the Nitre Class.

\begin{tabular}{|c|c|c|c|}
\hline & 4. & 2. & 1. \\
\hline $\begin{array}{l}\text { Nitrate of potash } \\
\text { Nitrate of ammonia .............. } \\
\text { Chloride of patassium . ....... } \\
\text { Chloride of ammonium ...... } \\
\text { Chlorate of potash............ }\end{array}$ & $\begin{array}{l}13 \cdot 97 \\
14 \cdot 48 \\
15 \cdot 01 \\
14 \cdot 41 \\
13 \cdot 31\end{array}$ & $\begin{array}{l}7 \cdot 47 \\
7 \cdot 73 \\
7 \cdot 70 \\
7 \cdot 81 \\
7 \cdot 22\end{array}$ & $\begin{array}{l}3 \cdot 72 \\
3 \cdot 75 \\
3 \cdot 88 \\
3 \cdot 89 \\
3 \cdot 66\end{array}$ \\
\hline Mean ...... & $14 \cdot 23$ & $7 \cdot 58$ & $3 \cdot 78$ \\
\hline
\end{tabular}

It is interesting to observe how the chlorate of potash rises in the lower proportions and approaches to the normal rate of its class. The diffusion products of all the salts are obviously more uniform for the two than for the 4 per cent. solutions, and again more uniform for the 1 than for the 2 per cent. solutions. The extremes in the 1 per cent. solutions are 3.66 grs. chlorate of potash, and 3.89 grs. chloride of ammonium, which are as 1 to 1.0628 . We have here an approach to equality in diffusion, which appears to be as close as the experimental determinations are of the specific heat of different bodies belonging to one class. The numbers for the specific heat of equivalents of the metallic elements are known to vary as 38 to 42 .

The salts of potash thus appear to fall into two groups of very similar if not equal diffusibility. What is the relation between these groups?

The diffusion of 4 per cent. solutions of carbonate and nitrate of potash was repeated at a temperature rising gradually from $63^{\circ}$ to $65^{\circ}$ during the seven days of the experiment, with a mean of $64^{\circ} \cdot 1$. The diffusion products of the carbonate were $10.31,10.05$ and 10.4 .4 grs, in three cells; mean 10.27 grs. Of the nitrate, $13.98,13.86$ and 13.60 grs.; mean 13.81 grs. We have thus a diffusion in equal times of -
Carbonate of potash . . 10.27
Nitrate of potash . . . 13.81
1 $1 \cdot 3447$

These experiments are almost identical with the former results, 10.25 carbonate of potash, and 13.97 nitrate of potash.

But the numbers thus obtained cannot be fairly compared, owing to the diminishing progression in which the diffusion of 
a salt takes place. Thus when the diffusion of nitrate of potash was interrupted every two days, as in a former experiment with chloride of sodium, the progress of the diffusion for eight days was found to be as follows in a 4 per cent. solution, with a mean temperature of $66^{\circ}$.

\section{Nitrate of Potash.}

$\begin{array}{ll}\text { Diffused in first two days } & \cdot 4.54 \mathrm{grs} \\ \text { Diffused in second two days } & \cdot 4 \cdot 13 \mathrm{grs} \\ \text { Diffused in third two days } & \cdot 4.06 \mathrm{grs} \\ \text { Diffused in fourth two days } & \frac{3.18}{15.91}\end{array}$

The absence of uniformity in this progression is no doubt chiefly due to the want of geometrical regularity in the form of the neck and shoulder of the solution phial. A plain cylinder, as the solution cell, might give a more uniform progression, but would increase greatly the difficulties of manipulation.

The diffusion of carbonate of potash will no doubt follow a diminishing progression also; but there is this difference, that the latter salt will not advance so far in its progression, owing to its smaller diffusibility, in the seven days of the experiment, as the more diffusible nitrate does. The diffusion of the carbonate will thus be given in excess, and as it is the smaller diffusion, the difference of the diffusion of the two salts will not be fully brought out.

The only way in which the comparison of the two salts can be made with perfect fairness, is to allow the diffusion of the slower salt to proceed for a longer time, till in fact the quantity diffused is the same for this as for the other salt, and the same point in the progression has therefore been obtained in both; and to note the time required. The problem takes the form of determining the times of equal diffusion of the two salts. This procedure is the more necessary from the inapplicability of calculation to the diffusion progression.

Further, allowing the Times of Equal Diffusion to be found, it is not to be expected that they will present a simple relation. Recurring to the analogy of gaseous diffusion, the times in which equal volumes or equal weights of two gases diffuse are as the square roots of the densities of the gases. The times, for instance, in which equal quantities of oxygen and hydrogen escape out of a vessel into the air, in similar circumstances, are as 4 to 1 ; the densities of these two gases as 16 to 1 . Or, the times of equal diffusion of oxygen and protocarburetted hydrogen are as 1.4142 to 1 , that is as the 
square root of 2 to the square root of 1 ; the densities of these guses being 16 and 8 , which are as 2 to 1 . The densities are the squares of the equal-diffusion times. It is not therefore the times themselves of equal diffusion of two salts, but the squares of those times which are likely to exhibit a simple relation.

(1.) While the 4 per cent. solution of nitrate of potash was diffused as usual for seven days, the corresponding solution of carbonate of potash was now allowed to diffuse for $9 \cdot 90$ days; times which are as 1 to $1 \cdot 4,142$, or as 1 to the square root of 2.

The results were as follows: diffused of-

Nitrate of potash at $64^{\circ} \cdot 1$, in seven days, $13.81 \mathrm{grs} .100$ Carbonate of potash at $64^{\circ} \cdot 3$, in 9.9 days, 13.92 grs. 100.8

The three experiments on the nitrate of potash, of which $13.81 \mathrm{grs}$. is the mean, were $13.98,13.86$ and $13.60 \mathrm{grs}$, as already detailed. The three experiments on the carbonate were $14.00,13.97$ and $13.78 \mathrm{grs}$. The difference in the means of the two salts is only $0.1 .1 \mathrm{gr}$. The results appear to be as near to equality as could be reasonably expected from the method of experimenting. Seven and 9.90 may therefore be considered as the times of equal diffusion indicated for nitrate and carbonate of potash. The times of equal diffusion, or the diffusibilities of nitrate and carbonate of potash, would appear therefore to be in the proportion of the square root of 1 to the square root of 2 .

The explanation of such a relation suggested by gaseous diffusion has been anticipated. It is that the two salts have different densities in solution, that of nitrate of potash being 1 , and that of carbonate of potash 2. We are thus led to ascribe, what may be called Solution Densities, to the salts. The two salts in question are related exactly like protocarburetted hydrogen gas, of density 1, to oxygen gas of density 2. The parallel would be completed by supposing that the single volume of oxygen to be diffused was previously mixed with 100 volumes of air (or any other diluting gas), while the 2 volumes of protocarburetted hydrogen were also diluted with 100 volumes of air; the diluting air here representing the water in which the salts to be diffused are dissolved in the solution cell. The time in which a certain quantity of protocarburetted hydrogen would come out from a vessel containing 1 per cent. of that gas being 1 (the square root of density 1), the time in which an equal quantity of oxygen would diffuse out from a similar vessel containing 1 per cent. also would be 1.4142 (the square root of density 2 ). 
(2.) A solution of 4 parts of sulphate of potash in 100 water was diffused simultaneously with the last solution of carbonate of potash, and therefore in similar circumstances. The diffusion products of three experiments were $14 \cdot 46,14 \cdot 21$ and 14.53 grs.; mean 14.40 grs. This is in the proportion of 104.27 sulphate of potash to 100 nitrate of potash; so that the approximation to equality of diffusion with nitrate of potash, in the selected times, is not so close for the sulphate as for the carbonate of potash.

(3.) The diffusion was repeated of 2 per cent. solutions of the nitrate and carbonate of potash at a lower temperature by about $10^{\circ}$. The temperature of the solutions was rather unsteady; ranging from $56^{\circ}$ to $52^{\circ} \cdot 25$ for the first period of seven days, from $56^{\circ}$ to $50^{\circ} .5$ for the period of 9.90 days, and from $55^{\circ}$ to $50^{\circ} .5$ for a second period of seven days; the external atmospheric temperature having fallen during the same period more than 20 degrees. Six phials of each solution were diffused and evaporated two together; so that the results are all double quantities.

At a mean temperature of $54^{\circ} \cdot 3$, the nitrate of potash gave in seven days 12.60 and 12.13 grs.; mean 12.36 grs.

Again, at a mean temperature of $52^{\circ} \cdot 4$, the nitrate of potash gave in seven days $11.85,12.40$ and 11.95 grs.; mean 12.06 grs.

The carbonate of potash gave in 9.90 days, with a mean temperature of $53^{\circ} .4,12.69,12.40$ and 12.12 grs.; mean $12 \cdot 40$ grs.

The general results are-

Nitrate of potash, in seven days, at 54.0.3 . 12.36 grs. Carbonate of potash, in 9.9 days, at $53^{\circ} .4$. 12.40 grs. Nitrate of potash, in seven days, at $52^{\circ} \cdot 4$. $12.06 \mathrm{grs}$.

As the first nitrate is $0^{\circ .9}$ above the carbonate and the second nitrate $1^{\circ}$ below it, we may take the mean of the two nitrates as corresponding to the temperature of the carbonate. We thus finally obtain, diffused at $53^{\circ} \cdot 4$, of -

Nitrate of potash in seven days, $12 \cdot 22$ grs. . 100

Carbonate of potash in 9.9 days, 12.40 grs. . $101 \cdot 4.7$

The difference in the amount of the diffusion of the two salts in these times is only $0.18 \mathrm{gr}$., or $1 \frac{1}{2}$ per cent.

These last experiments may be held therefore as tending to the same conclusion as the former series, although the circumstances were more than usually unfavourable to their success. To find whether the same relation existed between the salts through a considerable range of temperature, an opportunity 
was taken during cold weather to repeat the experiments at a low temperature.

(4.) Solutions of 1 salt in 100 water were diffused from eight solution cells, for each salt. The times were increased, but the same ratio of 1 to $1: 4142$ was preserved between them. The liquids of the cells were found to retain a temperature ranging slowly between $41^{\circ}$ and $38^{\circ} .8$ during the whole period of the observations. Sulphate of potash was substituted for the carbonate, as of these two equi-diffusive salts the former had been fourd to be least in accordance with nitrate of potash; in the 4 per cent. solutions, and appeared therefore to afford the severest test of the relation.

For nitrate of potash, at a mean temperature of $39^{\circ} \cdot 7$, during nine days, the diffusion product of two cells together was $6.97,6.93,6.77$ and 6.64 grs. ; mean 6.83 grs. for two cells.

For sulphate of potash, at the same mean temperature of $39^{\circ} \cdot 7$, during $12 \cdot 728$ days (twelve days, seventeen hours, twenty-eight minutes), the diffusion product of two cells together was $7 \cdot 05,6 \cdot 93,7 \cdot 28$ and $6 \cdot 90$ grs.; mean $7 \cdot 04$ grs. for two cells.

The general results are-

$\begin{array}{llll}\text { Nitrate of potash in nine days at } 39^{\circ} \cdot 7 \quad 6.83 \mathrm{grs} . & 100\end{array}$ Sulphate of potash in $12 \cdot 728$ days at $39^{\circ} \cdot 7 \quad 7 \cdot 04$ grs. 103.07

(5.) Solutions of 2 salt in 100 water were diffused simultaneously with the preceding experiments, and in precisely the same conditions of time and temperature.

The diffusion product of nitrate of potash during nine days, at a mean temperature of $39^{\circ} \cdot 7$, was $7 \cdot 03,6 \cdot 63,6 \cdot 83$ and $6 \cdot 83$ grs. for one cell ; mean 683 grs. for one cell, or the same number as for two cells with the 1 per cent. solution.

The diffusion product of sulphate of potash during $12 \cdot 728$ days was 6.84 , and 6.80 ; mean 6.82 grs. for one cell. These experiments almost coincide with the number for nitrate of pótash.

$$
\begin{aligned}
& \text { Nitrate of potash, } 6.83 \mathrm{grs} . \quad \cdot \quad \cdot \quad \cdot 100 \\
& \text { Sulphate of potash, } 6.82 \mathrm{grs} . \quad \text { - } \quad 99.85
\end{aligned}
$$

(6.) The existence of the relation in question was also severely tested in another manner. Preserving the ratio in the times of diffusion for the two salts, the actual times were varied in duration, in three series of experiments, as 1,2 and 3. The experiments were made in the vault, with a uniformity of temperature favourable to accuracy of observation. Eight cells of the 1 per cent. solution of each salt were always diffused at the same time.

(a.) Nitrate of potash diffused for 3.5 days, at $47^{\circ} \cdot 2$, gave 
for two cells, $3.55,3.63,3.33$ and 3.51 grs.; mean for two cells, 3.50 grs.

Sulphate of potash diffused for 4.95 days, at $47^{\circ} \cdot 3$, gave for two cells, $3.54,3.31,3.51$ and 3.63 grs.; mean for two cells, 3.50 grs., or exactly the same as for nitrate of potash above.

(b.) Nitrate of potash diffused for seven days, at $48^{\circ} \cdot 6$, gave $6 \cdot 1,6 \cdot 2,5 \cdot 9$ and 5.92 grs.; mean for two cells, 6.04 grs.

Sulphate of potash diffused for $9 \cdot 9$ days, at $49^{\circ} \cdot 1$, gave $6 \cdot 13,5 \cdot 92,6 \cdot 18$ and 6.59 grs.; mean $6 \cdot 20$ grs., or, excluding the last experiment, 6.08 grs.

Chromate of potash diffused also for 9.9 days, at $49^{\circ} \cdot 1$, gave $6 \cdot 19,6 \cdot 18,6 \cdot 40$ and 6.38 grs.; mean for two cells, $6 \cdot 29$ grs. The diffused chromate presented no appearance of decomposition on this occasion.

(c.) Nitrate of potash diffused for 10.5 days, at $48^{\circ}$, gave $8 \cdot 36,8 \cdot 95,8.82$ and 8.84 grs.; mean for two cells, 8.74 grs.

Sulphate of potash diffused for 14.85 days, at $48^{\circ} \cdot 6$, gave $8.99,8.94,8.66$ and 8.56 grs.; mean for two cells, 8.79 grs.

The mean results for the three different sets of periods of diffusion are as follows :-

3.5 and $4 \cdot 95$
days
7 and 9.9 days $\left\{\begin{array}{l}\text { Nitrate of potash, at } 47^{\circ} \cdot 2,3.50 \mathrm{grs} .100 \\ \text { Sulphate of potash, at } 47^{\circ} \cdot 3,3 \cdot 50 \mathrm{grs} .100\end{array}\right.$
$\begin{aligned} & \text { Nitrate of potash, at } 48^{\circ} \cdot 6,6.04 \mathrm{grs} .100 \\ & \text { Sulphate of potash, at } 49^{\circ} \cdot 1,6 \cdot 20 \mathrm{grs} .102 .65 \\ & \text { Chromate of potash, at } 49^{\circ} \cdot 1,6.29 \mathrm{grs} .104 .14\end{aligned}$
days

The concurring evidence of these three series of experiments appears to be quite decisive in favour of the assumed relation of $I$ to 1.4142 , between the times of equal diffusion for the nitrate and sulphate of potash, and consequently of the times for the two classes of potash salts, of which the salts natined are types. The same experiments are also valuable as proving the similarity of the progression of diffusion, in two salts of unequal diffusibility. I shall return again to the relation between nitrates and sulphates, under the salts of soda.

\section{(8.) Hydrate of Potash.}

(1.) Eight cells of the 1 per cent. solution of pure fused hydrate of potash were diffused for seven days in the vault, with a temperature ranging only from $59^{\circ}$ to $58^{\circ}$, of which the mean was $58^{\circ} \cdot 6$. The product of four cells evaporated together was 17.57 grs. of hydrate of potash, and of the other four cells 17.19 grs.; mean 17.38 grs., or 4.345 grs. for one cell. The hydrate of potash was estimated from the chloride 
of potassium which it gave when saturated with hydrochloric acid. The diffusion product of sulphate of potash for seven days, at $58^{\circ} .5$, or almost the same temperature, was 10.75 grs. for the four cells, as already stated, and consequently $2 \cdot 64$ grs. for one cell. It thus appears that the hydrate of potash is greatly more diffusive than the sulphate of potash in the same period of seven days, namely, as $4 \cdot 34.5$ to $2 \cdot 64$. Such a result indeed is not inconsistent with the times of equal diffusion of these two substances, differing as much as 1 to 2 .

(2.) Of pure fused hydrate of potash, a 1 per cent. solution was diffused from four cells for 4.95 days at a mean temperature of $53^{\circ} \cdot 7$, against a 1 per cent. solution of nitrate of potash in six cells, for seven days, at a mean temperature $0^{\circ} \cdot 1$ lower, or of $53^{\circ} 6$. The hydrate of potash which diffused, is calculated as before from the chloride of potassium which it gave, when neutralized by hydrochloric acid. Hydrate of potash diffused from two cells 5.97 and 6.28 grs. ; mean $6.12 \mathrm{grs}$, or $\$ .06$ grs. for a single cell.

Nitrate of potash diffused from two cells $6.22,6.54$ and 5.93 grs.; mean 6.23 grs., or 3.11 grs. for a single cell. The diffusion of nitrate of potash being 100 , that of the hydrate of potash is 98.2 , numbers which are sufficiently in accordance. But the times were as 1 to $1 \cdot 4142$, and their squares as 1 to 2 . So far then as this series of experiments on hydrate of potash entitles us to conclude, we appear to have for the salts of potash a close approximation to the following simple series of squares of equal diffusion times:-

\section{Squares of Times of Equal Diffusion, or Solution Densities.}

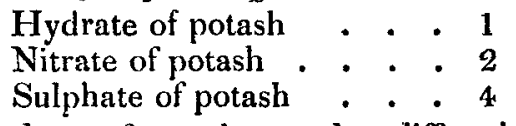

(3.) The hydrate of potash was also diffused at the lower temperature, $39^{\circ} \cdot 7$, in company with the nitrate and sulphate of potash for a period of 6.364 days (six days, eight hours, forty-four minutes).

The 1 per cent. solution of hydrate of potash gave in eight cells, evaporated two together, $6.93,6.93,6.93$ and 6.89 grs.; mean 6.92 grs.

The 2 per cent. solution of hydrate of potash gave in three single cells, $6 \cdot 77,6 \cdot 49$ and $7 \cdot 10$ grs.; mean $6 \cdot 79$ grs.

The diffusion of nitrate of potash in nine days at the same temperature, as already detailed, was sensibly the same, or 6.83 grs. for both the 1 and 2 per cent. solutions. The times for the two salts were as 1 to $1 \cdot 4 \cdot 142$.

The diffusion of hydrate of potash, at $39^{\circ} \cdot 7$, may therefore 
be stated with reference to that of nitrate of potash, for the selected times, as follows :-

Nitrate of potash, 1 and 2 per cent. solutions . 100

Hydrate of potash, 1 per cent. solution . . . 101.3

Hydrate of potash, 2 per cent. solution . . . 99.4

These experiments at the low temperature concur, therefore, with those made at the higher temperature, in proving that the times of equal diffusion of the two substances have been properly chosen.

[To be continued.]

XXXI. On Impossible Equalions, on Impossible Quantities, and on Tessarines. By J AMEs Cockle, Esq., M.A., of Trinity College, Cambridge; Barrister-at-Law, of the MiddleTemple*.

[Continued from vol. xxxvi. p. 292.]

DEINITIONS. By an impossible equation is meant an equation which has no root whatever capable of being expressed in terms of the symbols of the ordinary Double Algebra. By an impossible quantity is meant the new species of imaginary by which an impossible equation is supposed to be satisfied.

* Communicated by T. S. Davies, Esq., F.R.S. Lond, and Ed., who adds the following note.

"From my having become accidentally involved in the discussion of ' congeneric surd equations' (though merely from having called the attention of Mr. Horner to Garnier's equation, and not from any contribution of my own towards its elucidation), several of my friends, and some gentlemen who were strangers, have addressed their views on the subject privately to me. Those of Mr. Cockle, from the somewhat close agreement with my own, and from the form suitable for publication in which they were drawn up, 1 have sent for insertion in the Philosophical Magazine. Most others were put in forms that wonld have required modification for the purpose ; and this I did not feel myself at liberty to make, lest I should fail to express in my own language the exact view of the writers. There is one friend, however, a very enninent analyst, who takes a view directly opposed to these; and he has given me at different times his own explanation of most of the equations that have been hitherto mooted. When I state that, being opposed to his views (the opposition being founded, as I conceive, on the general principles of analysis), and yet having been uniformly unsuccessful in detecting any specifis fallacy in bis reasoning, I cannot view the question as being settled. On this account it is that I think the discussion should be kept open; and I trust that the gentleman to whom I refer will afford us the benefit of having his 'vein of thought' laid open in his own way. Exceptions and failing cases are always the most instructive subjects of inquiry in every science :-in analysis they always betoken something yet left to be seen or done.

"On one point, however, I wish to be distinctly understood; viz. as not expressing the slightest opinion, at present, on the subject of Quaternions, Tessarines, or any of the inquiries into which $i, j k$ enter." 